\title{
The Neolithic evolution and cultural transformations in the Povolzhye region (Eastern Europe)
}

\author{
Aleksandr Vybornov ${ }^{1}$, Konstantin Andreev ${ }^{1}$, Anatoly Somov ${ }^{1}$, and Marianna Kulkova ${ }^{2}$ \\ 1 Samara State University of Social Sciences and Education, Samara, RU \\ vibornov_kin@mail.ru \\ 2 Russian State Pedagogical University, St. Petersburg, RU
}

\begin{abstract}
The article is devoted to the analysis of Neolithic cultures in the Povolzhye region. Several synchronic archaeological complexes were compared. New data about the development and cultural changes of Neolithic communities were obtained. The processes of transition in the development of Neolithic cultures of the Povolzhye region were considered.
\end{abstract}

KEY WORDS - Neolithic; Volga region; pottery; evolution of cultural processes, transformation, chronology

\section{Neolitska evolucija in kulturne spremembe $v$ porečju reke Volge (Vzhodna Evropa)}

\begin{abstract}
IZVLEČEK - V članku predstavljamo analizo neolitskih kultur iz porečja reke Volge. Primerjali smo več sočasnih arheoloških kompleksov. Pridobili smo tudi nove podatke o razvoju in kulturnih spremembah neolitskih skupnosti. Obravnavali smo procese tranzicije v razvoju neolitskih kultur na območju Volge.
\end{abstract}

KLJUČNE BESEDE - neolitik; območje Volge; lončenine; evolucija kulturnih procesov; spremembe; kronologija

\section{Introduction}

The territory under consideration is characterised by several landscape zones: the semi-arid zone of the Northern Cis-Caspian, steppe of the Low Volga basin, forest-steppe and forest zones of the Middle Volga basin (Fig. 1). They differ in their environmental-climatic conditions. According to the results of pollen analysis for the studied sites in different regions, there were no cardinal differentiations during the Neolithic period nor in the present time (Morgunova 1997; Vasiliev et al. 1989; Yudin 2004).

The Neolithic cultures that existed in these conditions have differences in their identities. Earlier investigations paid attention to the study of the technology of pottery, the typology of the stone inventory, the construction of dwellings, household pro- cesses, and so on. However, this the evolutionary and transformational factors of cultural development have not been considered yet, although recent work on the determination of the chronological frameworks of Neolithic sites in the Povolzhye region have made this possible. We thus have the opportunity to answer questions about the reasons and mechanisms of evolution and change in the Neolithic cultures in this region.

\section{Materials and methods}

Many multidisciplinary methods of analysis have been applied to materials from archaeological sites in studied area, such as: typology (Vybornov 2008), stratigraphy (Koltsov 2005; Yudin 2004; Kulkova et 
al. 2019), analysis of pottery technology (Vasilieva 1999; 2011; Bobrinsky, Vasilieva 2012; Vybornov, Vasilieva 2013), radiocarbon dating (Vybornov et al. 2017; 2018), archaeozoology (Vybornov et al. 2015), geochemistry (Kulkova et al. 2019), and pollen analysis (Morgunova 1995; Yudin 2004; Vybornov 2008).

The materials of the Neolithic cultures from the archaeological sites of Povolzhye have been comprehensively studied in the decades from the 1980s to the present time. The artefacts from the sites of the Northern Cis-Caspian region, like Kugat IV (Komarov, Kozin 1989), Kairshak III (Vasiliev et al. 1989), Tenteksor (Vasiliev et al. 1986), and Zhekalgan (Kozin 1989), were investigated. The Kairshak-Tenteksorskaya culture was distinguished by I. B. Vasiliev (Vasiliev et al. 1988). More recently, the Baibek site belonging to this culture was discovered by Tatiana Yu. Grechkina et al. (2014). The pottery of the Kairshak-Tenteksorskaya culture is characterised by flatbottom vessels. In the early stage the ornamentation was presented by dash lines and separated pricks (Fig. 2). In the later period the ornamentation came in the form of pricks in the retreated technique (Fig. 3). Stone implements are represented by slabs and flakes. In the earlier stage segments prevailed (Fig. 4), while trapezes with processing on all external surfaces appeared in the later stage (Fig. 5). The dwelling structures have a circular form.

In the north-eastern Cis-Caspian the Dzhangar and Tu-Buzgu-Huduk sites were studied (Koltsov 2004). On the basis of material culture of these site the Dzhngarskaya culture was distinguished (Koltsov 2004). The ceramics are presented by flat-bottom pottery. The ornamentation is in form of triangular pricks in the retreated technique (Fig. 6). The stone implements are presented by slabs and flakes. Segments, trapezes and parallelograms prevailed in all period of development of this culture (Fig. 7). The dwelling structures have a circular form.

In the steppe zone of the Low Volga region, the Orlovka (Mamonov 1976) and Varfolomeevka (Yudin 1988) sites were investigated, and the 0rlovskaya culture was distinguished on the basis of this work (Yudin 2004). The Algay site was found relatively recently (Yudin et al. 2016). The pottery is characterised by flat-bottom vessels ornamented with triangular pricks in the retreated technique (Fig. 8). The stone implements are presented by slabs and flakes. Segments prevailed in the early stage, while in the later stage trapezes with processing on all external surface were developed (Fig. 9). The dwelling structures have a rectangular form.

In the forest-steppe zone of the Middle Povolzhye region the Staro-Elshanian II (Vasiliev et al. 1977), Ivanovskaya (Morgunova 1995) and Chekalino IV (Mamonov 1995) sites were studied. The Elshanian culture was determined on the basis of archaeological materials from these sites (Vasiliev, Vybornov 1988; Mamonov 1999). Subsequently the sites of Vyunovo ozero I (Berezina et al. 2013) and Utuzh I (Andreev et al. 2015) were discovered. The vessels have both pointed and flat bottoms. Several vessels have no ornamentation, but others have a row of pits or strokes under the corolla (Fig. 10). The stone implements are presented by slabs and flakes. The points of arrows have a petiolar shape (Fig. 11). The dwelling structures have a rectangular form. Later, the Srednevolzhskaya Neolithic culture spread in this region (Vasiliev, Vybornov 1988). The reference

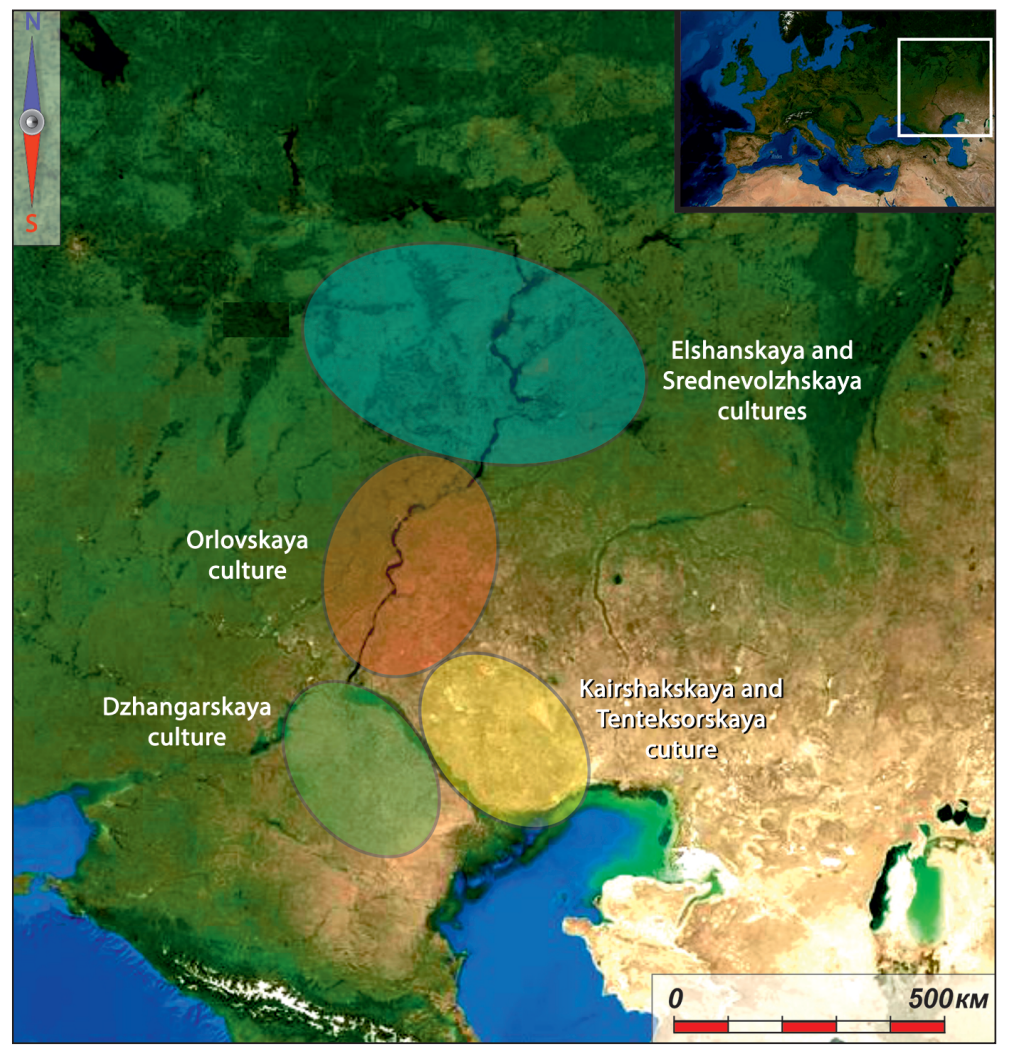

Fig. 1. The map of the Neolithic cultures in the Povolzhye region. 
sites of this culture are the Vilovatovskaya (Vasiliev et al. 1980), the Iliinskaya (Mamonov 1988), and the Lebyazhinka IV site (Vybornov et al. 2007). At the present time the Kalmikovka I site is still being excavated (Andreev et al. 2017). The pottery has flat bottoms, while the decoration was done by a tooth stamp and with help of the prick technique (Fig. 12). Stone implements are represented by slabs and flakes. The dwelling structures have a rectangular form.

In order to better understand the Neolithic cultural processes in this region their chronological frame-

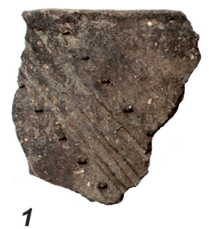

1
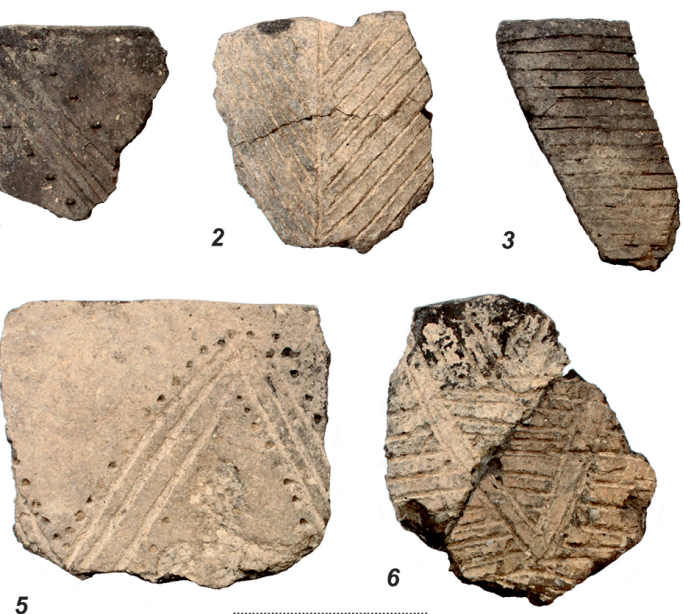

\begin{tabular}{llllll|l|}
0 & 1 & 2 & 3 & 4 & 5 & 5
\end{tabular}

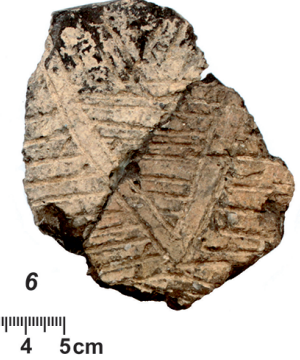

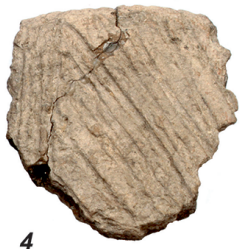

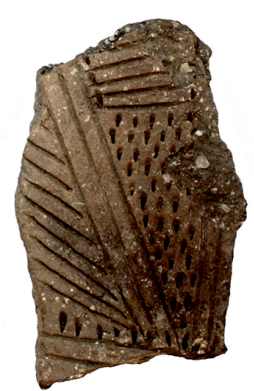

Fig. 2. The pottery of Kairshak type.

works should be determined. The series of radiocarbon dates for all archaeological sites were thus obtained, and this allowed us to determine that the Northern-Cis-Caspian culture developed from $c .6500$ to $5500 \mathrm{cal} \mathrm{BC}$, while the cultures in the North-Western Cis-Caspian existed from $c .6300$ to $5500 \mathrm{cal} \mathrm{BC}$. The development of the cultures in the steppe zone of the Low Volga River region continued from $c$. 6500 to 5300 cal BC. In the Middle Volga basin the Elshanian culture is dated from c. 6500 to $5500 \mathrm{cal}$ $\mathrm{BC}$, and the following Srednevolzhskaya culture was developed from c. 5500 to $4800 \mathrm{cal} \mathrm{BC}$ (Vybornov et al. 2017; Vybornov et al. 2018a; 2018b).

According to some researchers (Yudin 200; Koltsov 2005), one of the main factors of cultural change in the North-Western Cis-Caspian region and in the steppe of the Low Povolzhye was the appearance of domestication. However, the results of the archaeozoological analysis of materials from Neolithic sites in the region showed that all the bones belong to

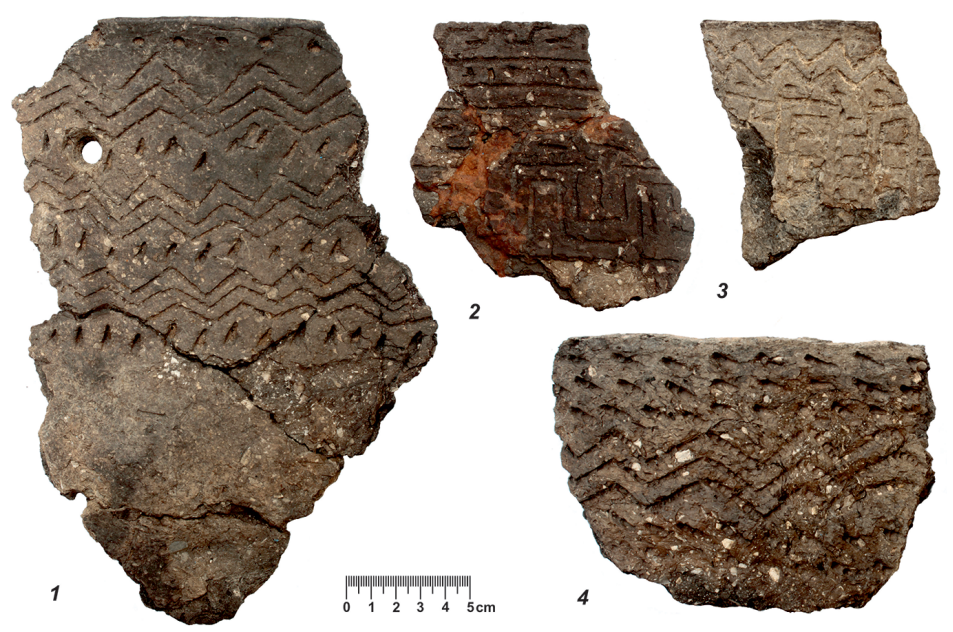

Fig. 3. The Tenteksor type of ceramics. wild animals (Vybornov et al. 2015). Moreover, lipid analysis of charred food crusts from Neolithic pottery of these sites did not determine any traces of milk production (Vybornov 2018b). At the same time the typological analysis shows obvious evidences of changes in the ceramic and stone inventory. The technique and technological analysis of pottery gives additional information about these changes (Bobrinsky 1978; Bobrinsky, Vasilieva 2012; Vybornov, Vasilieva 2013).

\section{Results and discussion}

The criteria used to distinguish between the Mesolithic and Neolithic in the Russian archaeological school are established on the basis of the appearance of new technologies in the tool industry and ceramic manufacture.

A comparison of the stone inventories of the Mesolithic and the Early Neolithic complexes from the Northern and North-Western Cis-Caspian shows close similarities. This allows us to suggest that the formation of the Early Neolithic in this region was a result of the evolution of the local Mesolithic communities (Koltsov 2005; Vybornov 2008). The pottery from the earliest sites have both pointed and flat bottoms. It is important to note that there are ceramics with similar technological features but with some differences in the same region (pottery from the Northern Cis-Caspian, for example). This could be evidence for a complex process in the initial stage of ceramic manufacture. Later, c. $6200 \mathrm{cal} \mathrm{BC}$, the flat-bottom 
1

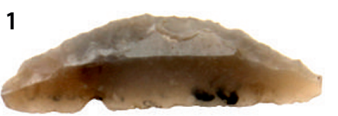

2
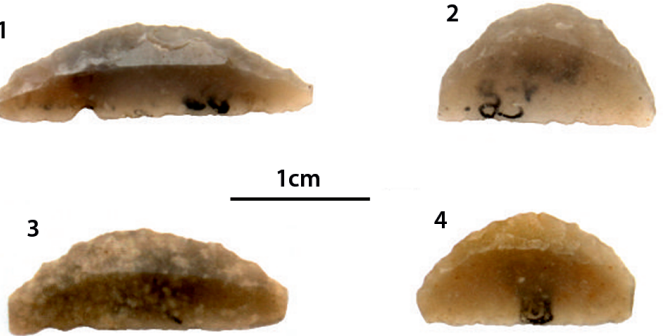

Fig. 4. The microliths of Kairshak type.

vessels became the dominant shape of pottery. Silt with a lot of shells was used for ceramic manufacture. According to some authors (Vasilieva 1999) this ceramic paste is the most ancient technology proto-ceramics. Silt clay is a good material for the hand manufacture of pottery in the early stage. Silt clay can contain shells and some amount of sand. There are different percentages of natural sand in the silt clay. The development of the ceramic tradition can also be considered from the perspective of the use of raw materials. The process of pottery manufacture develops with the use of silt clay with a lower sand content than in the earlier stage. For example, the content of sand in the silt clay used in the ceramic paste of pottery from the Kugat site is $100 \%$, from the Kairshak III site it is $41 \%$, and from the Tenteksor site it is only $4 \%$. This shows dynamic transformations of ceramic manufacture from the Early to the Late Neolithic.

The decoration of pottery changed from the dash technique to the prick retreated technique, as seen in pottery from the Baibek site, and this may be evidence of evolution rather than external influences, and the stone inventory also confirms an evolutionary process. We register the replacement of one geometric microlithic type (segments) in earlier complexes for other type (trapezes with processing on

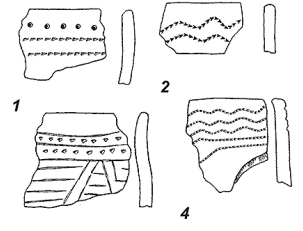

3
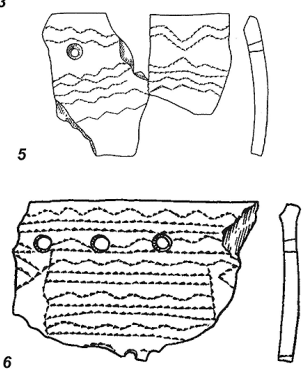
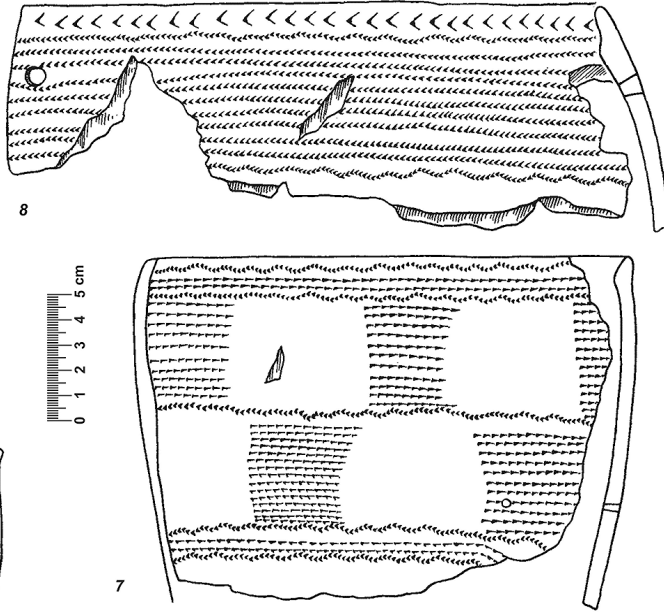

Fig. 6. The pottery of Dzhangarskya culture. all external surface) in the later stage. In the collections of stone artefacts of the Kairshak I sites there are trapezes with characteristics of later types ( $V y$ bornov, Kozin 1988). Most likely such a variant of development is connected with the territorial specifics of the Northern Cis-Caspian region, a steppe region that was not attractive to communities, especially in the periods of aridization. Therefore, the development of the Neolithic culture in this region was due to evolution and not external effects.

Another process of Neolithic development was revealed in the Northern-Western Cis-Caspian region. The earliest pottery here is characterised by some typological features like pits under the corolla and pointed bottoms, characteristics that are absent in
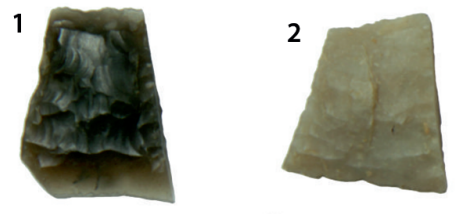

3
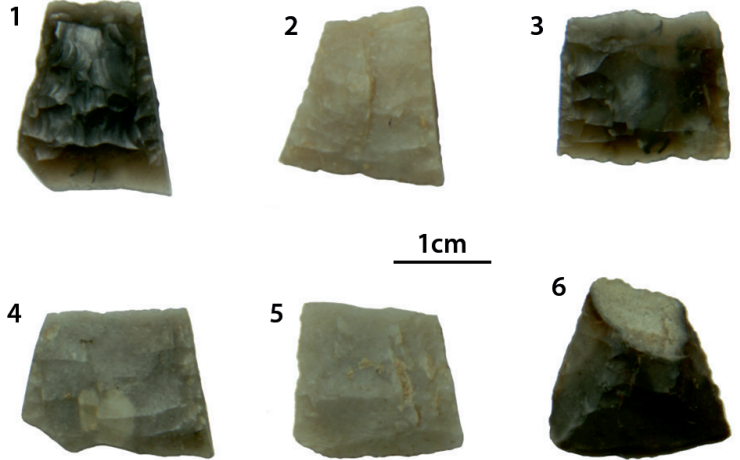

Fig. 5. The microliths of Tenteksor type.

neighbouring regions. They are thus not stable indicators, and this is evidence of the unstable tradition in the initial phase followed by a process of evolution. Characteristics of the pottery, like pricked ornamentation in a retreated technique, mark the autochthonous process of development, as those cultures of neighbouring regions lacked such typological features around c. $6300 \mathrm{cal} \mathrm{BC}$. In the second stage of development vessels with flat bottoms vessels appeared in the Dzhangarskaya culture, and these were common during the earliest Neolithic stage in this region. At the same time, the second stage pottery not only had typical pricked ornamentation, but also streaked ornamentation in combination with separated pricks of oval shapes (Fig. 6.3). These characteristics are typically of the Kairshak type of pottery, and confirm the appearance of carriers of this culture on the right shore of the Volga. In this case we cannot exclude the possibility of external influences on the cultural changes found here. 
In the northern steppe zone of the Low Povolzhye the Neolithic cultures could be formed on the local Mesolithic basis, with similarities to the Istayskaya group of the Mesolithic period in the Northern Cis-Caspian region. This is supported by complexes of the Istayskii type in the basin of Bol'shoy and Malii Uzen' (Lastovskii, Komarov 1988). Unfortunately, very early Neolithic sites which are similar to the Kugat or the Tu-Buzgu-
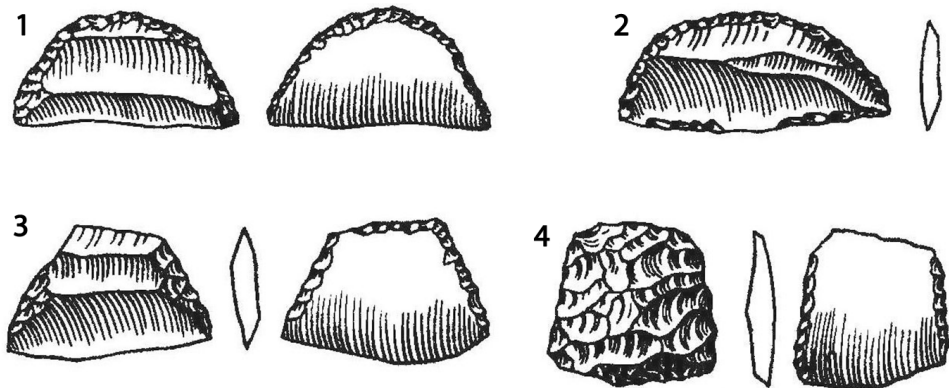

Fig. 7. The microliths of Dzhangarskya culture.

Khuduk have not yet been found. On other hand, the pottery from the bottom layer of the Varfolomeevskaya site, dated to $c .6500 \mathrm{cal} \mathrm{BC}$, was made using the Northern-Cis-Caspian technology from silt raw materials (Vasilieva, Vybornov 2016). The system of pottery decoration by dashes, and the dominance of segments among other microliths on this site, confirm that the primary influence was from southern regions. In the first stage of development the pottery technology shows the use of silt raw materials, while in the second stage silt loam is used, followed by clay. By contrast, in the Northern Cis-Caspian region ceramics were made from silt raw material throughout the Neolithic period (Vasilieva, Vybornov 2016). The Neolithic process in the Low Volga basin shows a clear evolution, with no evidence of the cultural influence of other societies in the materials of the Orlovskaya culture. Moreover, no cultures have been found in adjacent regions that show any development of a ceramic technology similar to one from the Low Volga basin. This can probably be explained by the landscape conditions of this area, which is in a dry steppe zone exposed to climatic aridization in
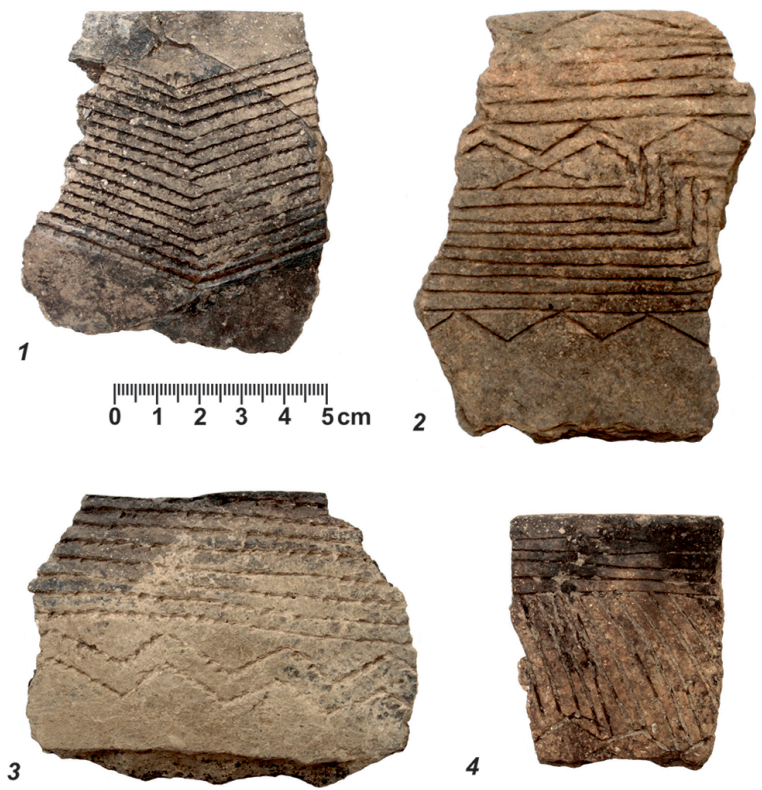

Fig. 8. The pottery of Orlovskaya culture. some periods of the Holocene (Kulkova et al. 2019). Because of such an adverse environment the communities of the Orlovskaya culture were isolated and not influenced by other cultural impulses.

In the materials of the Northern, North-Western CisCaspian and the Low Povolzhye from the later stage of the Neolithic period there is pottery with a thickening of the corolla on the inner part of vessels (Figs. 6, 8). The simultaneous appearance of this type of pottery in different regions could be interpreted as a result of cultural relationships. However, there are some problems with this thesis. For example, the percentage of items with a thickness of upper part of corolla in the Cis-Caspian region does not exceed $1 \%$, while in the materials of the Later Orlovskaya culture this figure is $20 \%$. The shapes of the thicknesses in section of the Tenteksor and Dzhangar pottery are oval and small, while the corolla thicknesses of the Orlovskii pottery has a rectangle form and large size. The Orlovskii type of pottery has decoration on the corolla's thickness, but the Cis-Caspian pottery does not. There are differences in the chronology of the appearance of this element. In the Cis-Caspian region this element appeared around $5500 \mathrm{cal} \mathrm{BC}$, while in the Low Volga basin on the Varfolomeevka site this element was developed about $5700 \mathrm{cal} \mathrm{BC}$. Therefore we can suggest that this technological element appeared independently in different regions as a result of the evolution of a ceramic manufacture.

In the forest-steppe of the Middle Povolzhye region in the early stage of the Elshanian culture (6500$5800 \mathrm{cal} \mathrm{BC}$ ) the vessels are characterised by a profile form, pointed bottoms, and row of pits under the corolla (Fig. 10.1-4). The technology has some differences from the ceramic pastes of pottery from the Cis-Caspian sites, which consisted of silt composed of shells, but the ceramics from the Povolzhye sites were made of loam, which was sometimes tempered by grog (Vasilieva 2011). This last technology is more elaborated, and this can be considered 


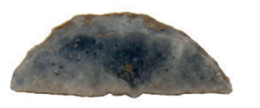

1

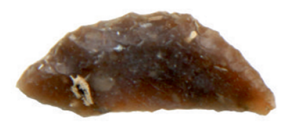

5

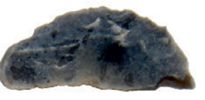

2
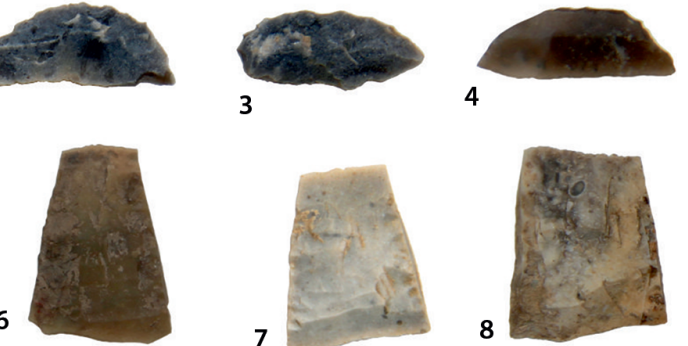

$\mathrm{cm}$
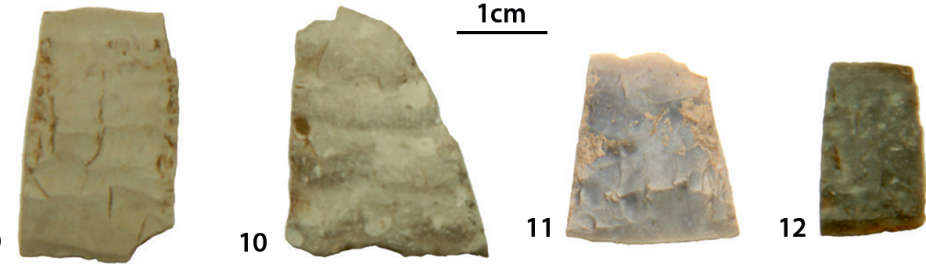

Fig. 9. The microliths of Orlovskaya culture.

as due to relationships among communities from different regions, and not the evolution of local Mesolithic societies (Vasilieva, Vybornov 2016). Around $6200 \mathrm{cal} \mathrm{BC}$ this type of pottery was developed not only in the Samara Povolzhye but also in the basin of the Sura river. These vessels have some differences in comparison with the Elshanian pottery (Vasilieva, Vybornov 2014), which can be explained by adaptation of pottery technology among the local Mesolithic community. In the second stage (5700$5500 \mathrm{cal} \mathrm{BC}$ ) of the development of Elshanian pottery in the Samara-Sok region the pointed bottom vessels gave way to flat bottom vessels (Fig. 10.5). In the Sura river basin, profiled undecorated vessels with pointed bottoms were developed until $c .5500$ cal BC. Such ceramics were produced without changes for some 700 years, and thus it can be concluded that in this region without any external impacts the earliest ceramic tradition of the Elshanian culture was preserved. This is an example of the evolution of pottery technology. On the other hand, the Samara-Sok basin is located in closed contact with the Low Povolzhye steppe region. The appearance of communities from the southern region to the foreststeppe zone began in the Mesolithic period. Therefore the appearance of the flat bottom vessels in the forest-steppe zone could be explained by cultural changes that occurred

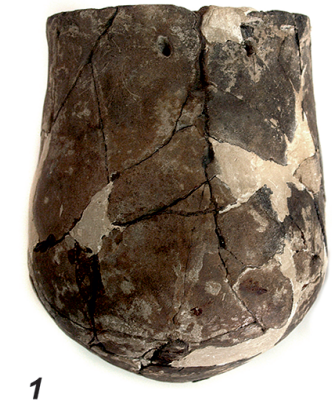

as a result of contacts with steppe societies.

Vessels with flat bottoms were found at the Krasniy Gorodok and the Ilinskaya sites (Vasilieva, Vybornov 2016a). Groups following the Elshanian cultural traditions saved specific elements of pottery manufacture without visible changes. These people did not have contact with migrants from southern regions, although some southern traditions appeared in this region at this time.

There are several characteristics of syncretic vessels, which are southern characteristics like flat bottoms and some percentage of crushed shells in the ceramic paste. The production process in the Low Volga region also concludes with a combination of dashes with oval pricks.

At end of the later stage of development, the Elshanian culture became a basis for the formation of new Srednevolzhskaya culture. This process cannot be attributed to evolution, because some vessels have been found in the Samara-Sura basin that are similar to both pottery from the Low Volga basin and the Northern Cis-Caspian region (Vasiliev et al. 1980; Vasilieva, Vybornov 2012; Vybornov et al. 2007). This is not due to the borrowing of pottery but the result of the direct penetration of individ-
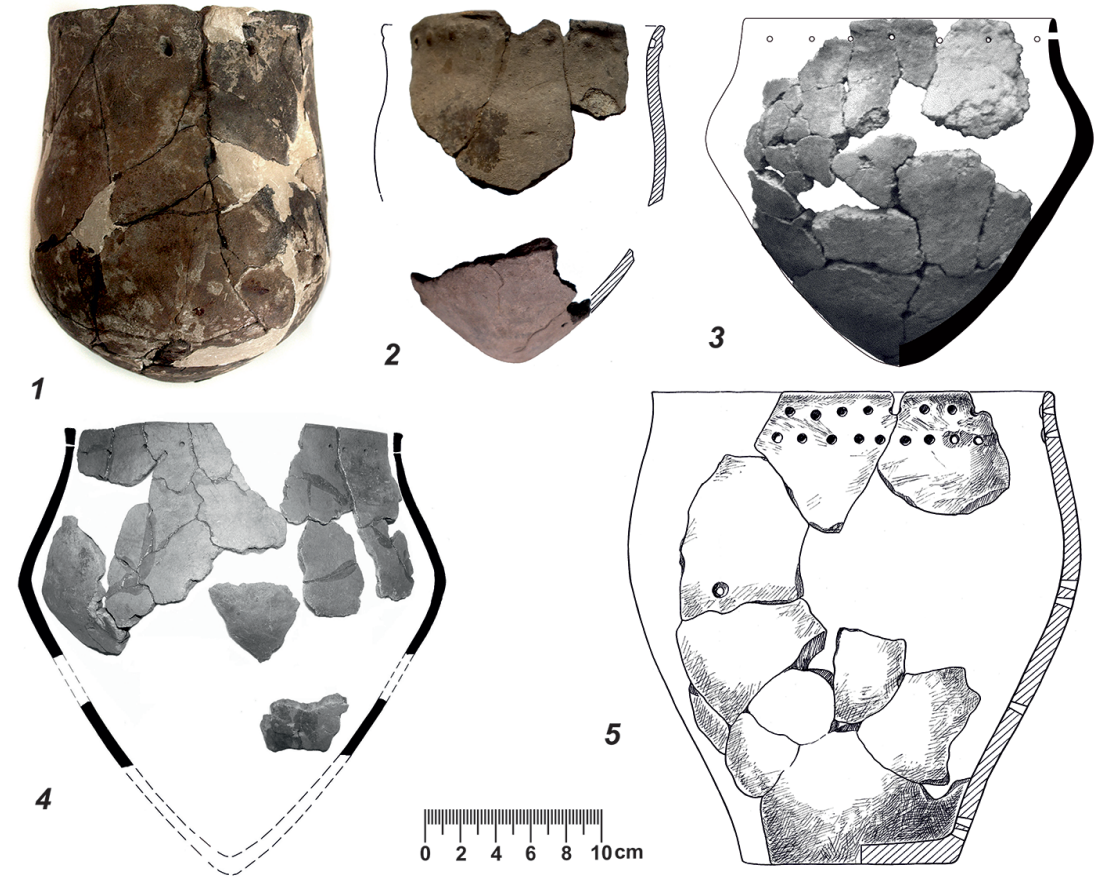

Fig. 10. The pottery of Elshanskaya culture. 
ual groups from southern regions to the foreststeppe Povolzhye region. The segments and trapezes with pretreatment of all the external surfaces are typical for the forest-steppe southern sites. They are the markers of geometric microliths of the Orlovskaya culture of the steppe Povolzhye. Several vessels from the southern parts of the forest steppe Povolzhye and decorated with pricks were manufactured in accordance with the style of the later stage of Elshanian ceramics. Other samples were made with using ceramic paste tempered with shells, as in the Northern Cas-Caspian region (Vasilieva, Vybornov 2013; 2016a). In other words, the genesis of the Srednevolzhskaya culture is not one of a process of evolution, but rather the result of cultural syncretism. Both the cultural components existed at the same time. The later Elshanian complexes are dated to the interval from $c .5700$ to $5500 \mathrm{cal} \mathrm{BC}$, while the Tenteksor and Later Orlovskaya cultures were developed from c. 5700 to 5300 cal BC (Vybornov et al. 2018). The climatic factors, such as aridization of the semi-arid and steppe regions of the Povolzhye, were triggers for migration into the forest-steppe areas (Kulkova et al. 2019). In the later periods some groups of the later Elshanian stage and the earlier Srednevolzhskaya stage penetrated into the southern periphery of the forest zone of the Middle Povolzhye region (Vybornov 2008). It could thus be possible that cultural factors impacted on the development of the local Mesolithic people, although at present this remains under discussion.

\section{Conclusions}

The complex analysis of the materials from several areas of the Povolzhye shows evidence of different variants of evolutionary development and transformation as a result of cultural influences. In the initial stage in the Northern and North-Western Cis-Caspian regions the ceramics and stone inventory developed on an autochthonous basis, and then evolved from this. In the Northern Cis-Caspian region the isolated development of the Neolithic culture occurred during the whole period, because of the local environmental conditions. The Dzhangarskaya culture, in spite of its
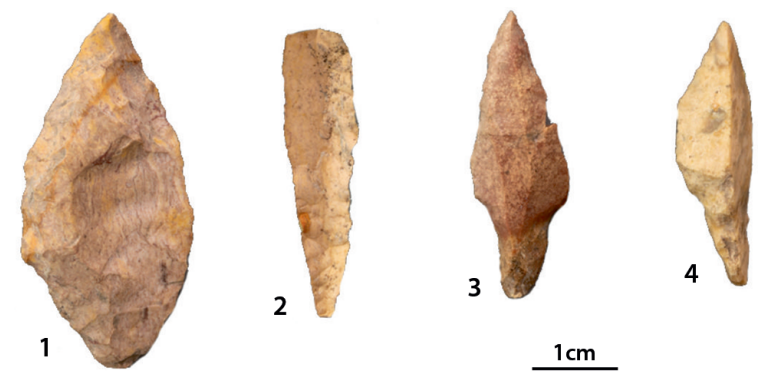

Fig. 11. The points of arrows of Elshanskaya culture.

evolutionary development, was also in part transformed under influence of the Kairshak traditions. The Orlovaskaya culture of the steppe Povolzhye was formed due to southern cultural impulses that were triggered by aridization, although its further development occurred due to evolution because of the resulting territorial isolation. The appearance of the Elshanian culture in the forest-steppe zone of the Povolzhye region occurred as a result of migrations of people from Middle Asia, and thus its cultural components had been formed earlier in this region.

Separate groups of people penetrated in the region of the Sura river, and their cultural traditions developed without any changes over a long period in this area. In the eastern part of the forest-steppe of

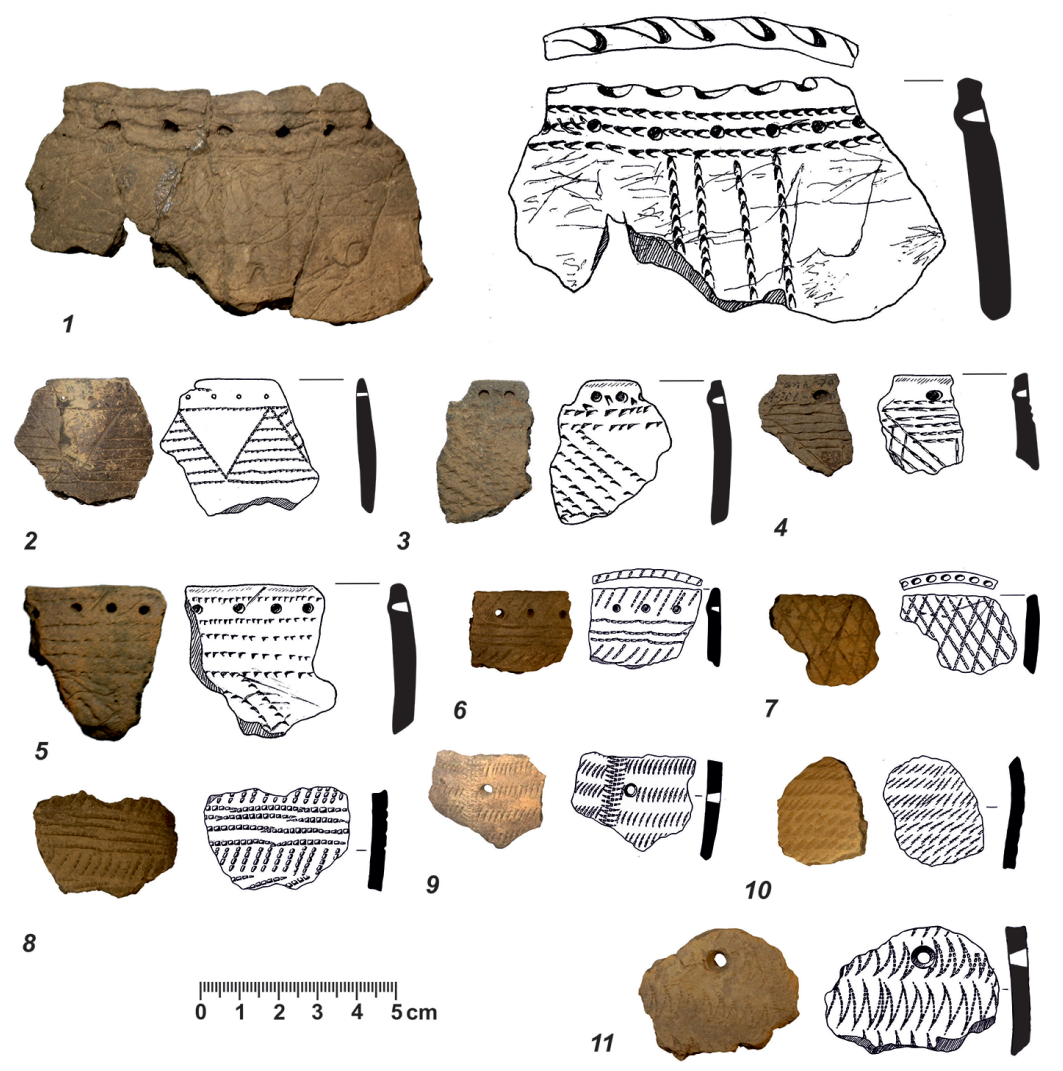

Fig. 12. The pottery of Srednevolzhskaya culture. 
the Povolzhye, and in the second stage of development, the Elshanian culture changed because of cultural impulses from the steppe Povolzhye. The next process was the interaction of the Orlovskaya culture, which penetrated into northern regions, and the Elshanian culture. On this foundation the new Srednevolzhskaya culture was formed.

\section{ACKNOWLEDGEMENTS}

The study was prepared with the help of a grant from the Russian Science Foundation, project no. 19-7810001 'Ethnocultural interaction of the population of the Middle Volga in the Stone Age (Mesolithic-Eneolithic)', RFBR no. 18-09-00040, RFBR no. 18-09-00568.

\section{References}

Andreev K. M., Berezina N. S., Berezin A. Yu., Vybornov A. A., Korolev A. I., and Sidorov V. V. 2015. Ranneneolitichesky keramichesky kompleks stoyanki Utyuzh I (po materialam raskopok 2011-2012 godov). Tverskoj arheologichesky sbornik 10: 266-274. (in Russian)

Andreev K. M., Vybornov A. A., Vasileva I. N., and Somov A. V. 2017. Neoliticheskie materialy stoyanki Kalmykovka I. Izvestiya Samarskogo nauchnogo centra Rossiyskoy akademii nauk 19(3): 172-180. (in Russian)

Berezina N. S., Vybornov A. A., Stavicky V. V., and Berezin A. Yu. 2013. Ranneneoliticheskaya stoyanka V'yunovo ozero I v Srednem Posur'e. Tverskoj arheologichesky sbornik 9: 195-201. (in Russian)

Bobrinsky A. A. 1978. Goncharstvo Vostochnoj Evropy. Nauka Press. Moscow. (in Russian)

Bobrinsky A., Vasilyeva I. 2012. Plastic raw materialsin Neolithic pottery production. Documenta Praehistorica 39: 67-74. https://doi.org/10.4312/dp.39.4

Grechkina T. Yu., Vybornov A. A., and Kutukov D. V. 2014. Novaya ranneneoliticheskaya stoyanka Bajbek v Severnom Prikaspii. Samarsky nauchnyj vestnik 3(8): 79-90. (in Russian)

Koltsov P. M. 1988. Neoliticheskoe poselenie Dzhangar. In Arheologicheskie kul'tury Severnogo Prikaspiya. Kuibyshev State Pedagogical Institute Press. Kuibyshev: 5292. (in Russian)

1989. Ranneneoliticheskaya stoyanka Tu-Buzgu-Huduk v Severo-Zapadnom Prikaspii. Neolit i eneolit Severnogo Prikaspiya. Kuibyshev State Pedagogical Institute Press. Kuibyshev: 89-105. (in Russian)

2004. Poselenie Dzhangar. Chelovek i ego kul'tura $v$ neolite Severo-Zapadnogo Prikaspiya. »Novyj hronograf « Press. Moscow. (in Russian)

2005. Mezolit i neolit Severo-Zapadnogo Prikaspiya. »Voskresen'e« Press. Moscow. (in Russian)
Kozin E. V. 1989. Novye materialy po neolitu Severnogo Prikaspiya. Problemy arheologicheskogo izucheniya Dono-Volzhskoj lesostepi. Voronezh State Pedagogical University Press. Voronezh: 36-44. (in Russian)

Kozin E. V., Komarov A. M. 1989. Pamyatniki ranneneoliticheskogo vremeni v yuzhnoj chasti Volgo-Ural'skih peskov. Neolit $i$ eneolit Severnogo Prikaspiya. Kuibyshev State Pedagogical Institute Press. Kuibyshev: 6-17. (in Russian)

Kulkova M., Vybornov A., Yudin A., Doga N., and Popov A. 2019. New interdisciplinary research on Neolithic-Eneolithic sitesin the Low Volga River region. Documenta Praehistorica 46: 376-387. https://doi.org/10.4312/dp.46.23

Lastovsky A. A., Komarov A. M. 1988. Pamyatniki s mikroliticheskim inventarem nizov'ev r. Malyj Uzen'. Arheologicheskie kul'tury Severnogo Prikaspiya. Kuibyshev State Pedagogical Institute Press. Kuibyshev: 42-51. (in Russian)

Mamonov A. E. 1988. Il'inskaya stoyanka i nekotorye problemy neolita lesostepnogo Zavolzh'ya. Problemy izucheniya rannego neolita lesnoj polosy Evropejskoj chasti SSSR. UdIHLL UrB RAS USSR Press. Izhevsk: 92-105. (in Russian)

1994. Elshansky kompleks stoyanki Chekalino IV. Drevnie kul'tury lesostepnogo Povolzh'ya. Samara State Pedagogical Institute Press. Samara: 3-25. (in Russian)

19990 kul'turnom statuse elshanskih kompleksov. Voprosy arheologii Povolzh'ya 1: 15-43. (in Russian)

Mamontov V. I. 1974. Pozdneneoliticheskaya stoyanka Orlovka. Sovetskaya arheologiya 4: 254-258. (in Russian)

Morgunova N. L. 1995. Neolit i eneolit yuga lesostepi Volgo-Ural'skogo mezhdurech'ya. Orenburg State Pedagogical University Press. Orenburg. (in Russian) 
Vasiliev I. B., Penin G. G. 1977. Elshanskie stoyanki na r. Samare v Orenburgskoj oblasti. Neolit i bronzovyj vek Povolzh'ya i Priural'ya. Kuibyshev State Pedagogical Institute Press. Kuibyshev: 3-22. (in Russian)

Vasiliev I. B., Vybornov A. A. 1988. Neolit Povolzh'ya. Kuibyshev State Pedagogical Institute Press. Kujbyshev. (in Russian)

Vasiliev I. B., Vybornov A. A., Gabyashev R. S., Morgunova N. L., and Penin G. G. 1980. Vilovatovskaya stoyanka v lesostepnom Zavolzh'e. In Eneolit Vostochnoj Evropy. Kuibyshev State Pedagogical Institute Press. Kuibyshev: 151-189. (in Russian)

Vasiliev I. B., Vybornov A. A., and Kozin E. V. 1986. Poz dneneoliticheskaya stoyanka Tenteksor v Severnom Prikaspii. In Drevnie kul'tury Severnogo Prikaspiya. Kuibyshev State Pedagogical Institute Press. Kuibyshev: 6-31. (in Russian)

1989. Issledovanie neoliticheskoj stoyanki Kairshak III. In Neolit i eneolit Severnogo Prikaspiya. Kuibyshev State Pedagogical Institute Press. Kuibyshev: 18-45. (in Russian)

Vasilieva I. N. 1999. Goncharstvo naseleniya Severnogo Prikaspiya v epohu neolita. Voprosy arheologii Povolzh'ya 1: 72-96. (in Russian)

2011. Ranneneoliticheskoe goncharstvo Volgo-Ural'ya (po materialam elshanskoj kul'tury). Arheologiya, etnografiya i antropologiya Evrazii 2(48): 70-81. (in Russian)

Vasilieva I. N., Vybornov A. A. 2012. Neolitichesky keramichesky kompleks Vilovatovskoj stoyanki: morfologiya i tekhnologiya. Arheologicheskie pamyatniki Orenburzh'ya 10: 23-42. (in Russian)

2013. Morfologiya i tekhnologiya neoliticheskoj keramiki stoyanki Lebyazhinka IV v Samarskom Povolzh'e. Arheologiya vostochnoevropejskoj lesostepi 3: 52-70. (in Russian)

2014. Neoliticheskoe goncharstvo Sursko-Mokshanskogo mezhdurech'ya. Samarsky nauchnyj vestnik 3(8): 35-53. (in Russian)

2016. Vremya poyavleniya i dinamika rasprostraneniya neoliticheskih keramicheskih tradicy v Povolzh'e. Povolzhskaya Arheologiya 3(17): 135-151. (in Russian)

2016a. Neolitichesky keramichesky kompleks Il'inskoj stoyanki: datirovka i tekhnologiya. Arheologicheskie pamyatniki Orenburzh'ya 12: 5-20. (in Russian)
Vybornov A. A. 2008. Neolit Volgo-Kam'ya. Samara State Pedagogical University Press. Samara. (in Russian)

Vybornov A. A., Andreev K. M., Kulkova M. A., and Filippsen B. 2018a. Radiouglerodnaya hronologiya neolita Volgo-Kam'ya. Ural'sky istorichesky vestnik 3(60): 6677. (in Russian)

Vybornov A., Kosintsev P., and Kulkova M. 2015. The Origin of Farming in Lower Volga Region. Documenta Praehistorica 42: 67-75. https://doi.org/10.4312/dp.42.3

Vybornov A. A., Kozin E. V. 1988. Neoliticheskaya stoyanka Kairshak I v Severnom Prikaspii. In Arheologicheskie kul'tury Severnogo Prikaspiya. Kuibyshev State Pedagogical Institute Press. Kujbyshev: 92-105. (in Russian)

Vybornov A., Kulkova M., Andreev K., and Nesterov E. 2017. Radiocarbon chronology of the Neolithic in the Povolzhye (Eastern Europe). Documenta Praehistorica 44: 224-239. https://doi.org/10.4312/dp.44.14

Vybornov A., Kulkova M., Kosintsev P., Platonov V., Platonov S., Phillipsen B., and Nesterov E. 2018b. Diet And Chronology of Neolithic-Eneolithic Cultures (From 6500 To $4700 \mathrm{Cal} \mathrm{Bc}$ ) In The Low Volga Basin. Radiocarbon 6: 1597-1610. https://doi.org/10.1017/RDC.2018.95

Vybornov A. A., Mamonov A. E., Korolev A. I., and Ovchinnikova N. V. 2007. Neoliticheskaya keramika stoyanki Lebyazhinka IV v lesostepnom Povolzh'e. Vestnik Samarskogo gosudarstvennogo pedagogicheskogo universiteta: 107-155. (in Russian)

Vybornov A., Vasilieva I. 2013. Interdisciplinary research of the Neolithic Volga-Kama pottery. Documenta Praehistorica 40: 165-173. https://doi.org/10.4312/dp.40.13

Yudin A. I. 1988. Varfolomeevskaya neoliticheskaya stoyanka. In Arheologicheskie kul'tury Severnogo Prikaspiya. Kuibyshev State Pedagogical Institute Press. Kuibyshev: 142-172. (in Russian)

2004. Varfolomeevskaya stoyanka $i$ neolit stepnogo Povolzh'ya. Saratov State University Press. Saratov. (in Russian)

Yudin A. I., Vybornov A. A., Vasilieva I. N., Kosincev P. A., Kulkova M. A., Goslar T., Phillipsen B., and Barackov A. V. 2016. Neoliticheskaya stoyanka Algaj v Nizhnem Povolzh'e. Samarsky nauchnyj vestnik 3(16): 61-68. (in Russian) 